\title{
Costs of nursing procedures/interventions: an integrative literature review
}

\author{
Custos de procedimentos/intervenções de enfermagem: revisão integrativa da literatura \\ Gastos de procedimientos/intervenciones de enfermería: revisión integrativa de la literatura
}

\section{Paula Buck de Oliveira Ruiz' ORCID: 0000-0001-5598-6776}

Caroline Rife Nobrega' ORCID: 0000-0002-2444-0102

Cínthia Prates Vigna' ORCID: 0000-0001-9491-7503

Antônio Fernandes Costa Lima' ORCID: 0000-0002-3582-2640

'Universidade de São Paulo. São Paulo, São Paulo, Brazil.

How to cite this article: Ruiz PBO, Nobrega CR, Vigna CP, Lima AFC. Costs of nursing procedures/interventions: an integrative literature review. Rev Bras Enferm. 2020;73(Suppl 6):e20190351. doi: http://dx.doi.org/10.1590/0034-7167-2019-0351

Corresponding author:

Paula Buck de Oliveira Ruiz E-mail:paulabuckruiz@usp.br

EDITOR IN CHIEF: Dulce Barbosa ASSOCIATE EDITOR: Antonio José de Almeida Filho

Submission: 05-03-2019

Approval: 06-30-2020 ABSTRACT
Objectives: to analyze the scientific production of nurses regarding the costs of procedures/
interventions performed by nursing professionals. Methods: integrative literature review
with a sample of 17 primary articles selected from the CINAHL, Scopus, EMBASE databases
and the PubMed portal. Results: all studies were conducted in hospitals, with quantitative,
exploratory-descriptive studies, considering the case study method, with the description
of costs method adopted, and the number of Brazilian publications stood out (12; 70.58\%).
The calculation of direct costs was most common due to the absence/difficulty of accessing
information in the studied hospitals. This made it impossible to obtain the indirect costs that
would be necessary for the composition of the total cost. Conclusions: it was shown that
studies about the cost of procedures/interventions are still scarce, often covering only the
calculation of direct costs. Nurses need to develop studies on such costs using the same
methodology in different contexts of health care.
Descriptors: Nursing; Nursing Care; Costs with Health Care; Cost and Cost Analysis; Services Direct Costs.

\section{RESUMO}

Objetivos: analisar a produção científica de enfermeiros sobre os custos de procedimentos/ intervenções realizados por profissionais de enfermagem. Métodos: revisão integrativa da literatura com amostra de 17 artigos primários selecionados nas bases CINAHL, Scopus, EMBASE e no portal PubMed. Resultados: todos os estudos foram conduzidos em instituições hospitalares, com estudos quantitativos, exploratório-descritivos, na modalidade estudo de caso, com a descrição do método de custeio adotado, destacando-se o número de publicações brasileiras $(12 ; 70,58 \%)$. Prevaleceu a apuração dos custos diretos devido à ausência/dificuldade de acesso a informações, nos hospitais estudados, que possibilitassem também a obtenção dos custos indiretos que seriam necessários para a composição do custo total. Conclusões: evidenciouse que a produção de estudos sobre custeio de procedimentos/ intervenções ainda é escassa, abrangendo, frequentemente, apenas a apuração dos custos diretos. Indica-se a necessidade de os enfermeiros desenvolverem estudos sobre tais custos adotando a mesma metodologia em diferentes contextos de atenção à saúde. Descritores: Enfermagem; Cuidados de Enfermagem; Custos de Cuidados de Saúde; Custos e Análise de Custo; Custos Diretos de Serviços.

\section{RESUMEN}

Objetivos: analizar la producción científica de enfermeros sobre los gastos de procedimientos/ intervenciones realizados por profesionales de enfermería. Métodos: revisión integrativa de la literatura con muestra de 17 artículos primarios seleccionados en las bases CINAHL, Scopus, EMBASE y en el portal PubMed. Resultados: todos los estudios han sido conducidos en instituciones hospitalarias, con estudios cuantitativos, exploratorio-descriptivos, en la modalidad estudio de caso, con la descripción del método de costeo adoptado, destacándose el número de publicaciones brasileñas $(12 ; 70,58 \%)$. Prevaleció la apuración de los gastos directos debido a la ausencia/dificultad de acceso a informaciones, en los hospitales estudiados, que posibilitaran también la obtención de los gastos indirectos que serían necesarios para la composición del costo total. Conclusiones: se evidenció que la producción de estudios sobre costeo de procedimientos/intervenciones aún es escasa, abarcando, frecuentemente, apenas la apuración de los gastos directos. Se indica la necesidad de los enfermeros desarrollaran estudios sobre tales gastos adoptando la misma metodología en diferentes contextos de atención a la salud. Descriptores: Enfermería; Cuidados de Enfermería; Costos de Cuidados de Salud; Costos y Análisis de Costo; Costos Directos de Servicios. 


\section{INTRODUCTION}

According to the World Health Organization (WHO), the United States of America, Marshall Islands, Liberia, Sierra Leone, and Tuvalu are the countries that spend the most on health, between $15.2 \%$ to $22.1 \%$ of their Gross domestic product (GDP). However, these countries do not have equal access when compared to Canada and the United Kingdom, despite the fact that they spend less ${ }^{(1)}$. In Brazil, total spending in this sector is $8 \%$ of the GDP, with $3.6 \%$ being public from sources and $4.4 \%$ private ${ }^{(2)}$. In this economic setting, administrators experience a major challenge for the survival of health organizations, being driven to seek new forms of management, making efficient use of resources compatible with the improvement of services to the population ${ }^{(3)}$.

In view of the scarcity of resources, the increase in demand for health services of different complexities and the growing difficulties of financing of public and private sources, health professionals need to acquire specific knowledge on the theme "health costs".

In health organizations, nursing professionals consume a large amount of resources to enable the provision of services. Nurses are responsible for the management of human resources, especially because the nursing staff represents between $30 \%$ and $60 \%$ of the total staff of institutions. The nurses are also responsible for the material resources consumed in the entire care process ${ }^{(4)}$. They are considered important elements, since they assess the needs for material, physical, human and financial resources, analyzing the expenses of the units and participating in the budget planning ${ }^{(5)}$.

Among health professionals, nurses, when providing direct and indirect care in different contexts, have knowledge that enables the promotion of cost-effective care, since they know how to take into account the costs involved ${ }^{(6)}$. Therefore, they must be able to act in the rationalization of resources, in the control of waste and in the optimization of results. Thus, assuming an effective role in the economic management of services ${ }^{(7)}$. It has been observed, in literature, that care management can reduce costs, improve patient satisfaction and better health outcomes $s^{(8-10)}$.

Nurses can contribute to cost management by conducting studies that provide elements for the rationalization of the resource allocation process, the balance between costs and finances, and the increase in results, directing the redefinition of priorities and monitoring of productivity. From this perspective, this study was carried out considering that the development and publication of knowledge produced by nurses on the determination, evaluation and control/ minimization of costs have the potential to provide information that helps the best applicability of resources, improving the quality of care and avoiding the occurrence of losses that may compromise the economic viability of the services offered by health institutions.

\section{OBJECTIVES}

To analyze the scientific production of nurses on the costs of procedures/interventions performed by nursing professionals.

\section{METHODS}

This is an integrative review ${ }^{(11)}$ carried out to answer the guiding question: "What is the state of the art on the scientific publication of nurses on the costs of interventions/procedures performed by nursing professionals?"

The PICO strategy, which stands for Patient, Intervention, Comparison and Outcomes, was used. The "P" - patients, were those undergoing nursing procedures/interventions;"I"- procedures/interventions performed by nursing professionals; " $\mathrm{C}$ " - no intervention for comparison was established; and " $\mathrm{O}$ " - costs of procedures/interventions ${ }^{(12)}$.

In compliance with the methodological rigor required to conduct the integrative review, six steps ${ }^{(13)}$ were carried out: identification of the theme and selection of the research question; establishment of criteria for inclusion and search for studies in the literature; definition of the information to be extracted from the selected studies; evaluation of studies included in the integrative review; interpretation of results and presentation of the synthesis of contents and knowledge.

Searches were conducted in the electronic databases CINAHL - The Cumulative Index to Nursing and Allied Health Literature; LILACS - Latin American and Caribbean Literature in Health Sciences; EMBASE; BDENF - Nursing Database; and on the PubMed portal, which includes MEDLINE. The keywords nursing care; nursing costs; cost and cost analysis; and economics, nursing were selected from terms indexed in the structured vocabulary DeCS (Health Sciences Descriptors) and in the indexing vocabulary of articles from PubMed, the Medical Subject Headings (MeSH terms).

The inclusion criteria were: published primary articles, published by nurses, in Portuguese, English and Spanish, fully available, during a five-year period (2013 to 2017), whose methodology evidenced the calculation of the costs of procedures and interventions performed by nursing professionals.

To detail the information collected from the articles, an instrument was used that collected the following information: identification of the original article (title, journal, year of publication); objectives; methodological characteristics; local; data collection process; type of costing; main results; conclusions and identification of limitations and/or bias.

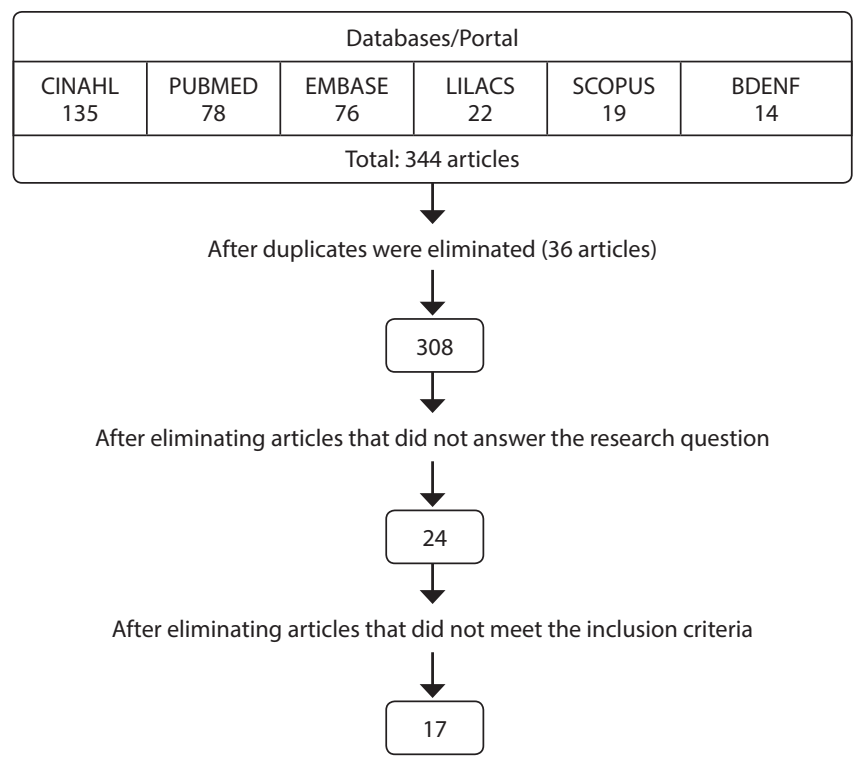

Source: Flowchart of selection and identification of studies following the PRISMA recommendations ${ }^{(14)}$ Figure 1 - Flowchart of the article inclusion process - São Paulo / SP, Brazil, 2018 
The initial research strategy identified 347 records. Of these, 36 were repeated, resulting in a total of 311 . The articles that answered the research question were 21 ; and after the inclusion criteria, 14 documents were selected. Figure 1 shows the details of this process.

For the analysis and synthesis of the 17 articles, a synoptic table containing title, year and country and another one with objective(s), method, results and recommendations/conclusions were used $^{(15)}$.

\section{RESULTS}

As shown in Chart 1, 17 primary articles ${ }^{(16-32)}(100 \%)$ comprised the sample of the present integrative review. All the studies analyzed were conducted in hospitals, having, among the authors, at least one nurse. Regarding the articles, they were published in Brazil $(12 ; 70.58 \%)$ and in the United States of America (USA) $(2 ; 11.76 \%)$, in the years $2015(7 ; 41.17 \%), 2014(5 ; 29.41 \%)$ and 2017 (4; 23.52\%); no publication from 2013 was found.

Charts 2, 3, and 4 show that all articles presented clear, concise and well-defined objectives, and sought to identify/calculate the average direct cost of the procedure/intervention under study. Most analyzed publications originated from quantitative, exploratory-descriptive studies, in a case study modality. The diversity of objects whose cost was evaluated is evident: installation, maintenance and disconnection of the patient-controlled analgesia pump; outpatient chemotherapy treatment for women with breast cancer; installation and disconnection of hemodialysis in patients with central venous catheter; nursing interventions in patients undergoing total hip arthroplasty; implementation of a pressure ulcer prevention protocol; conducting and documenting the Nursing Process; mobilization of patients aiming at the prevention of pressure injuries and dressings for the treatment of these injuries; process of reprocessing double and single cotton fabric fields, which are part of the surgical LAP package; nursing procedure for major burns; among others.

Among the main outcomes of the articles that comprised the sample ${ }^{(16-32)}$ (Charts 1, 2 and 3), the contributions highlighted were that the articles improve knowledge about: calculation and cost management; the importance of developing standard measurement methodologies to favor the comparison of the results of similar studies; and the need for studies to determine the indirect costs related to the assistance provided for the composition of the total cost.

Chart 1 - Characterization of the 17 primary articles included in the integrative review according to title, year, and country, São Paulo, São Paulo, Brazil, 2018

\begin{tabular}{|c|c|c|}
\hline Title & Year & Country \\
\hline Custo direto da instalação, manutenção e desligamento da bomba de analgesia(16) & 2014 & Brazil \\
\hline $\begin{array}{l}\text { Custo de procedimentos relacionados ao tratamento quimioterápico ambulatorial de mulheres portadoras de câncer de } \\
\text { mama }^{(17)}\end{array}$ & 2014 & Brazil \\
\hline Custo da instalação e desligamento de hemodiálise em pacientes com cateter venoso central ${ }^{(18)}$ & 2014 & Brazil \\
\hline Determining the cost-effectiveness of hospital nursing interventions for patients undergoing a total hip replacement ${ }^{(19)}$ & 2014 & USA \\
\hline Measuring direct nursing cost per patient in the acute care setting ${ }^{(20)}$ & 2014 & USA \\
\hline $\begin{array}{l}\text { Analysis of costs and benefits of transparent, gauze, or no dressing for a tunnelled central venous catheter in Canadian } \\
\text { stem cell transplant recipient }{ }^{(21)}\end{array}$ & 2015 & Canada \\
\hline Custo direto da condução e documentação do processo de enfermagem ${ }^{(22)}$ & 2015 & Brazil \\
\hline Custo direto da hemodiálise em unidade de terapia intensiva adulto ${ }^{(23)}$ & 2015 & Brazil \\
\hline Custo direto do reprocessamento de campos cirúrgicos de tecido de algodão: um estudo de caso ${ }^{(24)}$ & 2015 & Brazil \\
\hline Custos da implantação de um protocolo de prevenção de úlceras por pressão em um hospital universitário (25) & 2015 & Brazil \\
\hline Elderly patients and nurses assessment of traditional bed bath compared to prepacked single units-randomised controlled trial ${ }^{(26)}$ & 2015 & Denmark \\
\hline Mobilização corporal para prevenção de úlceras por pressão: custo direto com pessoal(27) & 2015 & Brazil \\
\hline Custo direto dos curativos de úlceras por pressão em pacientes hospitalizados ${ }^{(28)}$ & 2016 & Brazil \\
\hline Custo de procedimentos de enfermagem realizados com maior frequência ao grande queimado ${ }^{(29)}$ & 2017 & Brazil \\
\hline Custo direto da monitorização da hemodiálise convencional realizada por profissionais de enfermagem ${ }^{(30)}$ & 2017 & Brazil \\
\hline $\begin{array}{l}\text { The cost-effectiveness of a patient centred pressure ulcer prevention care bundle: Findings from the INTACT cluster } \\
\text { randomised trial| }{ }^{(31)}\end{array}$ & 2017 & Australia \\
\hline O custo do cateterismo vesical de demora nos pacientes internados na Unidade de Terapia Intensiva ${ }^{(32)}$ & 2017 & Brazil \\
\hline
\end{tabular}

Note: USA - United States of America; INTACT - Introducing a Care bundle to prevent pressure ulcer in at-risk patients. 
Chart 2 - Objective, synthesis of the design/sample, results and outcomes of the five articles published in 2014, São Paulo, São Paulo, Brazil, 2018

\begin{tabular}{|c|c|c|c|}
\hline Objective & Design/sample & Results & Outcomes \\
\hline $\begin{array}{l}\text { To identify the average total } \\
\text { cost (ATC) of installation, } \\
\text { maintenance and shutdown } \\
\text { of the patient-controlled } \\
\text { analgesia pump (PCA) } \\
\text { for infusion of morphine } \\
\text { or fentanyl in pain } \\
\text { management }^{(16)} \text {. }\end{array}$ & $\begin{array}{l}\text { Quantitative, exploratory- } \\
\text { descriptive research, in } \\
\text { the form of case study/ } 81 \\
\text { procedures. }\end{array}$ & $\begin{array}{l}\text { The installation's ATC was } R \$ 107.91 \\
\text { maintenance was } R \$ 110.55 ; \text { and } \\
\text { termination, } R \$ 4.94 \text {. The materials that } \\
\text { stood out the most were the PCA pump } \\
\text { equipment ( } R \$ 4.75 \text { each) and the } \\
\text { morphine solution bag ( } R \$ 31.71 \text { each). }\end{array}$ & $\begin{array}{l}\text { The results obtained will support } \\
\text { discussions on the need for monetary } \\
\text { transfers from the Unified Health } \\
\text { System to hospital units that carry } \\
\text { out this antalgic therapy and will } \\
\text { contribute to cost management } \\
\text { and rational allocation of resources } \\
\text { consumed. }\end{array}$ \\
\hline $\begin{array}{l}\text { To identify the ATC of } \\
\text { procedures related to } \\
\text { outpatient chemotherapy } \\
\text { treatment for women with } \\
\text { breast cancer }{ }^{(17)}\end{array}$ & $\begin{array}{l}\text { Quantitative, exploratory- } \\
\text { descriptive, with a case } \\
\text { study design/ } 60 \text { horizontal } \\
\text { observations; procedures } \\
\text { related to chemotherapy } \\
\text { treatment. }\end{array}$ & $\begin{array}{l}\text { The ATC, per chemotherapy session, } \\
\text { corresponded to } \mathrm{R} \$ 1,783.01(100 \%) \text {, } \\
\text { being } \mathrm{R} \$ 1,671.66(93.75 \%) \text { with drugs, } \\
\mathrm{R} \$ 74,98(4.21 \%) \text { with materials, } \mathrm{R} \$ 28.49 \\
(1.60 \%) \text { with human resources and } \\
\mathrm{R} \$ 7.88(0.44 \%) \text { with solutions. }\end{array}$ & $\begin{array}{l}\text { Knowledge of the costs associated with } \\
\text { chemotherapy treatment procedures } \\
\text { may support decision-making, aiming } \\
\text { at reducing expenses and eliminating } \\
\text { waste, without prejudice to the quality } \\
\text { of the service provided. }\end{array}$ \\
\hline $\begin{array}{l}\text { To identify the ATC } \\
\text { of the installation } \\
\text { and disconnection of } \\
\text { hemodialysis in patients with } \\
\text { central venous catheters }^{(18)}\end{array}$ & $\begin{array}{l}\text { Quantitative, exploratory- } \\
\text { descriptive research, in } \\
\text { the form of a single case } \\
\text { study/100 installations } \\
\text { and } 100 \text { hemodialysis } \\
\text { disconnections in } 42 \text { patients } \\
\text { with central venous catheter. }\end{array}$ & $\begin{array}{l}\text { The installation's ATC was } R \$ 80.10 \text {, } \\
\text { and the termination, } R \$ 13.04 \text {, totaling } \\
R \$ 93.14 \text { per hemodialysis session. } \\
\text { Material costs stood out: capillary } \\
\text { dialyzer, arterial line, and venous line, } \\
\text { costing } R \$ 36.15, R \$ 3.77 \text { and } R \$ 3.47 \text { each, } \\
\text { respectively. }\end{array}$ & $\begin{array}{l}\text { The results make it possible to plan } \\
\text { better the allocation of the resources } \\
\text { involved and help management } \\
\text { strategies aimed at economic } \\
\text { efficiency. }\end{array}$ \\
\hline $\begin{array}{l}\text { To identify the types } \\
\text { and values of nursing } \\
\text { interventions and estimate } \\
\text { the cost-effectiveness for } \\
\text { the complications that } \\
\text { patients experienced } \\
\text { when undergoing total hip } \\
\text { arthroplasty }{ }^{(19)}\end{array}$ & $\begin{array}{l}\text { Data collection was } \\
\text { carried out in three } \\
\text { electronic databases of } \\
\text { the hospital/254 patients } \\
\text { admitted for total hip } \\
\text { arthroplasty between } 2006 \\
\text { and } 2007 \text {. }\end{array}$ & $\begin{array}{l}\text { Patients with more comorbidities } \\
\text { were prone to receive hemotherapy, } \\
\text { medications, incentive spirometry and } \\
\text { hospitalization in a central care unit. } \\
\text { The average direct cost was US\$4,333, } \\
\text { ranging from US\$2,756 to US\$7,332. } \\
\text { About 48\% of patients incurred costs } \\
\text { between US\$ 4,000 and US\$4,999; } 35 \% \\
\text { between US\$3,000 and US } \$ 3,999 \text {. }\end{array}$ & $\begin{array}{l}\text { Using appropriate methods, } \\
\text { nurse managers can compare the } \\
\text { cost-effectiveness of new nursing } \\
\text { interventions or manage the supply } \\
\text { of more cost-effective nursing } \\
\text { interventions. }\end{array}$ \\
\hline $\begin{array}{l}\text { To measure the variability } \\
\text { of direct nursing costs for } \\
\text { similar patients and examine } \\
\text { the characteristics of nurses } \\
\text { assigned to different types of } \\
\text { patients }^{(20)}\end{array}$ & $\begin{array}{l}\text { The data for measuring costs } \\
\text { was collected from three } \\
\text { databases of hospitalized } \\
\text { patients from January } 2010 \text { to } \\
\text { December } 2012 \text { in a medical/ } \\
\text { surgical unit of a large hospital. }\end{array}$ & $\begin{array}{l}\text { The time required for nursing care } \\
\text { ranged from } 0.36 \text { to } 13 \text { hours; and the } \\
\text { daily cost per patient, from US\$32 to } \\
\text { US\$ } 1,455 \text {. } \\
\text { The average direct nursing cost per day } \\
\text { was US\$96.48 (SD = US\$ 55.73). }\end{array}$ & $\begin{array}{l}\text { The use of standard measurement } \\
\text { of nursing cost per patient can } \\
\text { be compared between hospitals, } \\
\text { informing the administrative } \\
\text { decisions in the provision of nursing } \\
\text { services. }\end{array}$ \\
\hline
\end{tabular}

Note: ATC - average total cost; PCA - patient-controlled analgesia pump; $R \$$ - reais; US\$-dollar; SD - standard deviation. OBS: One dollar was R\$3,31 in 2017.

Chart 3 - Objective, synthesis of the design/sample, results, and outcomes of the seven articles published in 2015, São Paulo, São Paulo, Brazil, 2018

\begin{tabular}{|c|c|c|c|}
\hline Objective & Design/sample & Results & Outcomes \\
\hline $\begin{array}{l}\text { To assess the impact of } \\
\text { three different nursing care } \\
\text { strategies for the tunneled } \\
\text { central venous catheter (CVC) } \\
\text { exit site and compare the } \\
\text { costs of each strategy }{ }^{(21)}\end{array}$ & $\begin{array}{l}\text { Micro-costing to assess the } \\
\text { costs and benefits of each } \\
\text { CVC/432 exit location care } \\
\text { strategy record (procedures) } \\
\text { at a single health institution. }\end{array}$ & $\begin{array}{l}\text { The transparent coverage required } \\
\text { weekly care (US\$ 51.79/week); the } \\
\text { group without coverage, daily care } \\
\text { (US\$ 56.34/week); and the gauze } \\
\text { dressing, every } 48 \text { hours (US\$ } 103.72 \text { / } \\
\text { week). }\end{array}$ & $\begin{array}{l}\text { The costs of supplies and labor for } \\
\text { the gauze dressing were considerably } \\
\text { higher, indicating that there are } \\
\text { better financial benefits from } \\
\text { discontinuing its use. }\end{array}$ \\
\hline $\begin{array}{l}\text { To identify the average direct } \\
\text { cost (ADC) of the activities } \\
\text { performed by nursing } \\
\text { professionals in order to } \\
\text { conduct and document the } \\
\text { Nursing Process (NP) in the } \\
\text { Medical Clinic Ward of a } \\
\text { university hospital (22) }\end{array}$ & $\begin{array}{l}\text { Quantitative, exploratory- } \\
\text { descriptive research, in } \\
\text { the form of a single case } \\
\text { study/1.040 NP conducting } \\
\text { and documenting activities. }\end{array}$ & $\begin{array}{l}\text { The ADC of the patient's admission } \\
\text { corresponded to } R \$ 55.57 \text { ( } S D= \\
\text { 19.44); among the patient follow-up } \\
\text { activities, the documentation of the } \\
\text { Nursing Evolution represented the most } \\
\text { impacting } A D C(R \$ 17.70, S D=14.60 \text { ); the } \\
\text { ADC of descriptive notes corresponded } \\
\text { to } R \$ 1.21(S D=1.21 \text { ), and the } A D C \text { of the } \\
\text { nursing team for work shift change was } \\
R \$ 54.23(S D=28.95) \text {. }\end{array}$ & $\begin{array}{l}\text { The study contributes to give } \\
\text { visibility to the performance of } \\
\text { nursing professionals in conducting } \\
\text { and documenting the NP, by } \\
\text { providing financial elements for } \\
\text { consistent arguments regarding the } \\
\text { resources suitable for its feasibility. }\end{array}$ \\
\hline $\begin{array}{l}\text { To identify the total ADC of } \\
\text { conventional hemodialysis } \\
\text { performed by nursing } \\
\text { technicians on patients with } \\
\text { acute kidney injury in an } \\
\text { Adult Intensive Care Unit } \\
\text { (23) }\end{array}$ & $\begin{array}{l}\text { Quantitative case study } \\
\text { research/57 conventional } \\
\text { hemodialysis sessions for } 23 \\
\text { patients with acute kidney } \\
\text { injury. }\end{array}$ & $\begin{array}{l}\text { The total ADC (R\$ } 434.83 \text { ) was impacted } \\
\text { by the costs of the "monitoring" stages } \\
R \$ 205.58, \text { "preparation of the machine } \\
\text { and the extracorporeal circuit", R\$ } \\
120.96 ; \text {; and "internal disinfection and } \\
\text { cleaning of the machine", } R \$ 42.10 \text {. }\end{array}$ & $\begin{array}{l}\text { As the study was restricted to } \\
\text { measuring only the direct cost. The } \\
\text { measure of indirect costs is a major } \\
\text { challenge to determine the total } \\
\text { costs. }\end{array}$ \\
\hline
\end{tabular}




\begin{tabular}{|c|c|c|c|}
\hline Objective & Design/sample & Results & Outcomes \\
\hline $\begin{array}{l}\text { To identify the ACD for the } \\
\text { process of reprocessing } \\
\text { double and single cotton } \\
\text { fabric fields, which are part of } \\
\text { the surgical LAP package }{ }^{(24)}\end{array}$ & $\begin{array}{l}\text { Quantitative, exploratory- } \\
\text { descriptive research, in the } \\
\text { form of a single case study/ } \\
\text { the stages and activities of } \\
\text { reprocessing were analyzed }\end{array}$ & $\begin{array}{l}\text { The ACD with cleaning labor, assistants } \\
\text { and nursing technicians and material for } \\
\text { making a surgical LAP package totaled } \\
\text { US\$ 9.72. The "assembly and sterilization } \\
\text { of the surgical LAP package" stage was } \\
\text { the most representative (US\$9.39); } \\
\text { the ADC for materials suffered a strong } \\
\text { impact from the costs of cotton fabric } \\
\text { fields (US\$ 7.99). }\end{array}$ & $\begin{array}{l}\text { The knowledge obtained will support } \\
\text { the nurse in discussions and in } \\
\text { decision making about the economic } \\
\text { feasibility of replacing reusable tissue } \\
\text { fields with disposable ones. }\end{array}$ \\
\hline $\begin{array}{l}\text { To calculate the direct costs } \\
\text { of implementing a pressure } \\
\text { ulcer (PU) prevention } \\
\text { protocol in a university } \\
\text { hospital }^{(25)}\end{array}$ & $\begin{array}{l}\text { Quantitative, exploratory- } \\
\text { descriptive study with a } \\
\text { single-case study design/ } \\
\text { the activities that comprise } \\
\text { the following stages were } \\
\text { mapped: elaboration, } \\
\text { implementation and } \\
\text { evaluation of the protocol. }\end{array}$ & $\begin{array}{l}\text { Costs totaled US\$ } 60,857.38(100 \%) \text {, } \\
\text { with US\$ } 38,297.64(62.93 \%) \text { related } \\
\text { to the direct labor of nurses, nursing } \\
\text { technicians/assistants and secretary; } \\
\text { and US\$ } 22,559.74(37.07 \%) \text { related } \\
\text { to the acquisition of products, } \\
\text { accessories, and equipment. }\end{array}$ & $\begin{array}{l}\text { Health professionals need to } \\
\text { value the financial aspects of care, } \\
\text { understanding that managing } \\
\text { them presupposes the increase of } \\
\text { resources to guarantee access and } \\
\text { equity to users associated with the } \\
\text { maintenance of quality of care. }\end{array}$ \\
\hline $\begin{array}{l}\text { To compare: (1) bath duration } \\
\text { and quality, }(2) \text { cost, }(3) \\
\text { nurse satisfaction and (4) } \\
\text { patient satisfaction with bed } \\
\text { baths using traditional basin } \\
\text { compared to bed bath with } \\
\text { disposable utensils }{ }^{(26)}\end{array}$ & $\begin{array}{l}\text { Randomized clinical trial, } \\
\text { with a group of patients } \\
\text { over } 19 \text { years of age, awake, } \\
\text { conscious, able to speak } \\
\text { and understand the local } \\
\text { language and who needed } \\
\text { to bathe in bed for two } \\
\text { consecutive days. }\end{array}$ & $\begin{array}{l}\text { The bath with disposable utensils } \\
\text { lasted less ( } 29 \text { minutes) when } \\
\text { compared to the bath using the } \\
\text { traditional basin ( } 36 \text { minutes). The bath } \\
\text { with disposable utensils cost } 11.84 \\
\text { DKK; and the bath using the traditional } \\
\text { basin, } 11.87 \text { DKK. In both, all nurses } \\
\text { were satisfied with the cleanliness } \\
\text { and the time spent; and all patients } \\
\text { interviewed were satisfied. }\end{array}$ & $\begin{array}{l}\text { In the case of baths with disposable } \\
\text { utensils, the costs are lower, since less } \\
\text { time is spent. } \\
\text { If the calculation included machines } \\
\text { (hot water and washing machine) } \\
\text { and electricity, the costs of the basin } \\
\text { method would have been even } \\
\text { greater than baths with disposable } \\
\text { utensils. }\end{array}$ \\
\hline $\begin{array}{l}\text { To calculate the average } \\
\text { total cost (ATC) related to } \\
\text { the direct labor of nursing } \\
\text { professionals involved } \\
\text { in mobilization activities } \\
\text { of patients admitted to a } \\
\text { university hospital aiming at } \\
\text { the prevention of PUs } \text { s }^{(27)}\end{array}$ & $\begin{array}{l}\text { Quantitative, exploratory- } \\
\text { descriptive case study/656 } \\
\text { preventive mobilizations for } \\
\text { PUs prevention in inpatient } \\
\text { units (medical, surgical, and } \\
\text { intensive care). }\end{array}$ & $\begin{array}{l}\text { The ATC for the medical clinic } \\
\text { corresponded to } R \$ 5.38 \text { for change } \\
\text { of position, } R \$ 5.26 \text { for positioning } \\
\text { the patient in an armchair, } R \$ 5.55 \text { for } \\
\text { helping during walks in the medical } \\
\text { clinic; for the surgical clinic, } R \$ 2.42 \\
\text { for changing position, } R \$ 2.30 \text { for } \\
\text { positioning in an armchair, } R \$ 2.96 \\
\text { for walking aid; in intensive care, } R \$ \\
8.15 \text { for changing position, } R \$ 7.57 \text { for } \\
\text { positioning in an armchair, } R \$ 15.32 \text { for } \\
\text { walking aid care. }\end{array}$ & $\begin{array}{l}\text { The results may support the cost } \\
\text { management related to the human } \\
\text { resources involved in the preventive } \\
\text { care of patients at risk of developing } \\
\text { PUs. }\end{array}$ \\
\hline
\end{tabular}

Note: CVC - central venous catheter; $A D C$ - average direct cost; NP - Nursing Process; $R \$$ - reais; US\$ - dollar; SD - standard deviation; ATC - average total cost; Pus - pressure ulcers.

Chart 4 - Objective, synthesis of the design/sample, results, and outcomes of the five articles published between 2016 and 2017 , São Paulo, São Paulo, Brazil, 2018

\begin{tabular}{|c|c|c|c|}
\hline Objective & Design/sample & Results & Outcomes \\
\hline $\begin{array}{l}\text { To identify the average direct } \\
\text { cost (ADC) related to the } \\
\text { direct labor force (DLF) of } \\
\text { nursing professionals and the } \\
\text { consumption of materials and } \\
\text { solutions when performing } \\
\text { dressings for the treatment } \\
\text { of pressure ulcers (PUs) in } \\
\text { hospitalized patients } \\
\text { (28) }\end{array}$ & $\begin{array}{l}\text { Single case study with } \\
\text { exploratorydescription/288 } \\
\text { dressings for the treatment } \\
\text { of patients with PUs. }\end{array}$ & $\begin{array}{l}\text { The ADC for PUs dressings corresponded } \\
\text { to US\$ } 19.18 \text { (PUs-category I); US\$ } 6.50 \\
\text { (PUs-category II); US\$ } 12.34 \text { (PUs-category } \\
\text { III); US\$ } 5.84 \text { (PUs-category IV); US\$ } \\
9.52 \text { (PUs-unclassifiable) and US\$ } 3.76 \\
\text { (suspected deep tissue injury). } \\
\text { The dressing of PUs-category I had } \\
\text { the highest ADC (US\$ } 45.70) \text {, with the } \\
\text { consumption of solutions and materials } \\
\text { being the most impactful items (US\$ } \\
\text { 16.23; SD } \pm 12.97) \text {. }\end{array}$ & $\begin{array}{l}\text { The determination of dressing } \\
\text { costs for the treatment of different } \\
\text { categories of PUs is vital for future } \\
\text { estimates, being the basis of the } \\
\text { budgeting and financing process } \\
\text { for each unit/service in health } \\
\text { institutions. }\end{array}$ \\
\hline $\begin{array}{l}\text { To identify the ADC of the } \\
\text { procedures most frequently } \\
\text { performed by nursing } \\
\text { professionals in an Intensive } \\
\text { Care Unit, for major burned } \\
\text { patients }^{(29)}\end{array}$ & $\begin{array}{l}\text { Quantitative, exploratory- } \\
\text { descriptive case study } / 883 \\
\text { observations relating to five } \\
\text { most frequent procedures } \\
\text { performed on critically ill } \\
\text { major burn patients. }\end{array}$ & $\begin{array}{l}\text { The ADC was US\$ } 0.65 \text { for "control of } \\
\text { vital signs"; and for "intravenous drug } \\
\text { administration" it was US\$ } 10.00 ; \\
\text { US\$ } 5.90 \text { for "measurement of diuresis"; } \\
\text { US\$ } 0.93 \text { for "capillary blood glucose } \\
\text { testing"; and US\$ } 99.75 \text { for "dressing". } \\
\text { Regarding dressing, the ADC with } \\
\text { material (US\$ } 57.69 ; \text { SD }=122.12 \text { ) had a } \\
\text { strong impact on the total direct cost. }\end{array}$ & $\begin{array}{l}\text { The knowledge developed } \\
\text { can support decision-making, } \\
\text { management, and assistance, as } \\
\text { well as minimize the costs of the } \\
\text { necessary materials. }\end{array}$ \\
\hline
\end{tabular}




\begin{tabular}{|c|c|c|c|}
\hline Objective & Design/sample & Results & Outcomes \\
\hline $\begin{array}{l}\text { To analyze the ADC regarding } \\
\text { the participation of nursing } \\
\text { professionals in the monitoring } \\
\text { procedure for conventional } \\
\text { hemodialysis, in three public } \\
\text { teaching and research } \\
\text { hospitals in the state of São } \\
\text { Paulo(30) }\end{array}$ & $\begin{array}{l}\text { Multiple case study with } \\
\text { an exploratory-descriptive } \\
\text { approach/657 procedures } \\
\text { for "monitoring the } \\
\text { hemodialysis session" in } \\
\text { three hospitals (A, B and C). }\end{array}$ & $\begin{array}{l}\text { The ADC for "monitoring the } \\
\text { hemodialysis session" was higher at } \\
\text { Hospital C (R\$ 184.52), being } 5.23 \text { times } \\
\text { higher than that of Hospital A (R\$ } \\
\text { 35.29) and } 3.91 \text { higher than Hospital B } \\
\text { (R\$ 47.22). }\end{array}$ & $\begin{array}{l}\text { The study proposes a costing } \\
\text { methodology that can be reproduced } \\
\text { in different dialysis centers and for } \\
\text { other dialysis procedures, directing } \\
\text { the decision-making process in } \\
\text { the efficient allocation of human } \\
\text { resources. }\end{array}$ \\
\hline $\begin{array}{l}\text { To evaluate the cost- } \\
\text { effectiveness of a patient- } \\
\text { centered pressure ulcers (PU) } \\
\text { care package compared to } \\
\text { standard treatment }{ }^{(31)}\end{array}$ & $\begin{array}{l}\text { Direct micro-costing study } \\
\text { related to an PU prevention } \\
\text { care package/317 patients } \\
\text { whose outcomes were: } \\
\text { diagnosis of new PU, hospital } \\
\text { discharge or transfer. }\end{array}$ & $\begin{array}{l}\text { The PU prevention care package costs } \\
\text { US\$ } 144.91 \text { more per patient compared } \\
\text { to standard treatment. The biggest } \\
\text { contributors to the increase in costs were } \\
\text { "nurse time for repositioning" and "skin } \\
\text { inspection". In the cost-effectiveness } \\
\text { analysis, it was estimated that the } \\
\text { package would cost US\$ } 3.296 \text { per } \\
\text { avoided PU. }\end{array}$ & $\begin{array}{l}\text { The package may result in } \\
\text { improvement of the clinical } \\
\text { practice associated with the care } \\
\text { of preventing PU in the hospital } \\
\text { context, however it may not be cost- } \\
\text { effective. }\end{array}$ \\
\hline $\begin{array}{l}\text { To assess the items of the } \\
\text { direct cost of the long- } \\
\text { standing bladder catheter } \\
\text { (CB) evaluation in patients } \\
\text { admitted to the Intensive } \\
\text { Care Units (ICUs) with } \\
\text { and without urinary tract } \\
\text { infections (UTI) }\end{array}$ & $\begin{array}{l}\text { Multiple case study, with } \\
\text { an exploratory-descriptive } \\
\text { design/Two groups were } \\
\text { observed: one of patients } \\
\text { hospitalized in two ICUs (A } \\
\text { and B) who used CB; and the } \\
\text { other of nurses coordinating } \\
\text { the ICUs. }\end{array}$ & $\begin{array}{l}\text { Urine collection system (R\$ 3.28); } \\
\text { lidocaine hydrochloride (R\$ } 1.38 \text { ) and } \\
\text { Foley catheter (R\$ } 0.86 \text { ) were the most } \\
\text { expensive items. The nurse at ICU A } \\
\text { received } R \$ 3.84 \text { for performing the } \\
\text { procedure, representing } 40.74 \% \text { less } \\
\text { than the nurse at ICU B (R\$ 6.48). The } \\
\text { estimated time varied between } 20 \text { and } \\
40 \text { minutes. ICU B had a higher total cost } \\
\text { in patients without UTI (R\$ } 13.26 \text { ) and } \\
\text { with UTI (R\$ } 257.07) ; \text { ICU A had costs of } \\
R \$ 10.62 \text { and } R \$ 202.70 \text {, respectively. }\end{array}$ & $\begin{array}{l}\text { The cost of passing CB, when } \\
\text { associated with the treatment of UTI, } \\
\text { totaled R\$ } 192.08 \text { in ICU A and R\$ } \\
243.81 \text { in ICU B. The UTI associated } \\
\text { with the CB represents an important } \\
\text { budgetary impact. }\end{array}$ \\
\hline
\end{tabular}

Note: $A D C$ - average direct cost; DLF - direct labor; PIs - pressure injuries; $R \$$ - reais; US\$ - dollar; SD - standard deviation; PU - pressure ulcers; CB - Iog-term bladder catheter; ICUs - Intensive Care Units; UTI - urinary tract infections.

\section{DISCUSSION}

The studies analyzed addressed a great diversity of procedures/ interventions to enable the provision of care, direct or indirect, performed by nursing professionals. Although most portray direct care procedures/interventions, it should be highlighted that indirect interventions are complementary to an efficient and effective care process, since care involves activities, processes, and decisions (direct or indirect) aimed at the individual, group or community in situations of health/illness ${ }^{(33)}$.

Most Brazilian articles ${ }^{(16-18,22-25,27-30,32)}$ corresponded to quantitative, exploratory-descriptive studies, in the case study modality. It is understood that the option for the case study is justified by the fact that this approach allows the investigation of contemporary phenomena, considering their real context; allows to evaluate multiple variables; and it can draw on different sources of evidence ${ }^{(34)}$.

The case study consists of a systematic analysis of multiple forms of information that make it possible to reach an understanding of a given context and of those inserted in it, preserving significant, complex and integral characteristics of the events, clarifying a decision or a set of decisions taken and implemented as its defined results, leading to an expanded understanding of phenomena and situations ${ }^{(34)}$.

Thus, case studies, like experiments, can be generalized into theoretical propositions, and not to populations or universes. As an experiment, they do not have a representative sample, and the researcher's objective is to expand and generalize theories (analytical generalization) and not to list frequencies (statistical generalization) $)^{(34)}$.
All Brazilian articles ${ }^{(16-18,22-25,27-30,32)}$ identified/calculated the monetary value of procedures/interventions in reais, through direct nonparticipant observation and the consumption of inputs (materials, medicines, and/or solutions) and the time (timed) spent by nursing professionals. Some of them ${ }^{(24-25,28-29)}$ converted the values originally obtained in reais to US dollars in order to favor the comparison of their results with studies carried out internationally. Regardless of the currency used to fund nursing procedures/interventions, the studies indicated that the methodology adopted could be reproduced for different procedures/interventions and emphasized that nurses, when performing the appropriate allocation of human, material, or financial resources, lead to improvements in the management strategies aimed at the economic efficiency of the health institutions in which they operate.

Some articles identified the average total $\operatorname{cost}^{(16-18,27)}$, but the authors obtained only the average direct cost. Most studies $^{(16-18,22-25,27-30)}$ indicated the determination of direct costs due to the lack of information, or difficulty in accessing it, in the contexts studied, which made it impossible to determine the indirect costs that would be necessary for the composition of the total cost (sum of direct and indirect costs) ${ }^{(35)}$ of nursing procedures/interventions.

Direct costs are defined as monetary expenses applied to the production of a product/service in which there is a possibility of identification with the product or department. They refer to all those who can be identified and clearly quantified. Indirect costs, on the other hand, are those that need some apportionment criteria for their proper appropriation, as there is no direct reference to a procedure or service. They are related to the product, 
but do not offer conditions for an objective measurement, and any attempt at allocation must be made through estimations, by apportionment ${ }^{(35)}$.

Even though it was not possible to determine the total cost in most of the studies analyzed, the fact that nurses carry out studies on the theme "costs", especially in hospital contexts, represents a contribution to the advance in this area of knowledge.

In Brazilian studies, direct costs were the main approach of international researches, considering, in addition to the material resources consumed, the time spent by professionals in measuring the total cost. Two articles ${ }^{(19,31)}$ addressed the costeffectiveness/value of the study objects, expanding the discussion by comparing different possibilities of interventions/procedures and the best outcomes in care practice. Economic evaluation studies - for example, of cost-effectiveness - are used to support decision-making regarding the adoption of new technologies, verifying the relationship between costs and benefits resulting from health interventions that are being or may be performed in a given reality. Cost-effectiveness studies can also be understood as an instrument for analyzing the value of these interventions, since the method seeks to fill the gap between preferences and scientific evidence (objectivity, validity, reproducibility) ${ }^{(36)}$.

All studies ${ }^{(16-32)}$ analyzed were conducted in hospital contexts, most of them dealing with highly complex procedures since they are associated with high health costs. From a managerial perspective, managing hospital costs has become a fundamental instrument for the control of resources, allowing the identification of more effective strategic paths and opportunities to find more profitable activities, as well as those whose expenses need to be analyzed and controlled, or which are not economically viable ${ }^{(37)}$.

Nursing professionals are in constant contact with patients. Thus, the nurse assumes an essential role in the management of costs and in the participation in the budget planning of health institutions, since they will be asked to manage human, material and financial resources, as well as to analyze the results of the assistance provided ${ }^{(6)}$. In this sense, it is considered essential that nurses, as managers of nursing care, even when they do not occupy formal managerial positions, invest in their training to develop studies that allow them to measure, analyze and control the costs of nursing procedures/interventions.

Ignorance about these costs makes any negotiation process impossible to adjust the price/cost ratio, hindering profits, returns, investments in infrastructure, educational and professional growth $^{(38)}$. Therefore, studying the cost management of procedures/ interventions leads, in addition to improving care, to the rational administration of human and material resources involved, albeit in finite quantities. Thus, it stands out that understanding and analyzing the costs of procedures/interventions is essential for managers and health professionals to effectively contribute to the proposal and adoption of measures that favor the financial sustainability of organizations ${ }^{(28)}$.

\section{Study limitations}

The different methods used in studies to determine costs, as well as the lack of continuity in carrying out studies on the same procedure/intervention in different care contexts, proved to be a limitation for the comparative analysis of the main results obtained.

\section{Contributions to the field of Nursing, Health or Public Policy}

The present study synthesized the objectives, methods, results, and recommendations/conclusions of studies on scientific production in relation to the determination of the costs of nursing procedures/interventions, showing the advances and limitations of knowledge on the subject.

\section{CONCLUSIONS}

In this integrative review, 17 primary studies published by nurses were found and analyzed, whose objects of investigation were the costs of nursing procedures/interventions. Most were quantitative, exploratory-descriptive studies, in the case study modality, with the explanation of the method for calculating costs covering the cost of material resources and/or the time spent by professionals.

It was evident that the production of studies on the cost of nursing procedures/interventions is still scarce, being restricted to the calculation of direct costs in hospital contexts. There is a need for nurses to contribute to the production of knowledge about costs, and health organizations must overcome the challenge of generating and making available reliable information, that allows the determination of indirect costs in order to calculate the total costs procedures/interventions, of varying complexities, in different contexts of health service provision.

\section{REFERENCES}

1. World Health Organization WHO. Browse data tables by topic [Internet]. 2016 [cited 2018 Aug 12]. Available from: http://apps.who.int/gho/ data/node.main.GHEDCHEGDPSHA\%202011.

2. Saldiva PHN, Veras M. Gastos públicos com saúde: breve histórico, situação atual e perspectivas futuras. Estud Av [Internet]. 2018 [cited 2018 Aug 12];32(92):47-61. Available from: http://www.scielo.br/pdf/ea/v32n92/0103-4014-ea-32-92-0047.pdf

3. Araújo EC, Pontes E. Análise da eficiência do gasto público com saúde [Internet]. Brasília: World Bank Group; 2017 [cited 2018 Aug 12 ]. Available from: http://portalarquivos2.saude.gov.br/images/pdf/2017/maio/26/1.a-Banco-Mundial-Eficiencia-do-Gasto-com-Saude-CIT.pdf

4. Fugulin FMT, Lima AFC, Castilho V, Bochembuzio L, Costa JA, Castro L, et al. Cost of nursing staffing adequacy in a neonatal unit. Rev Esc Enferm USP [Internet]. 2011 [cited 2014 Jul 08];45 (spe):1582-8. Available from: http://www.scielo.br/pdf/reeusp/v45nspe/en_v45nspea07.pdf

5. Castilho V, Fugulin FMT, Rapone RR. Gerenciamiento de costos en los servicios de enfermería. In: Kurcgant P, Tron-chin DMR, Peres HHC, Massarellon MCKB, Fernandes MFP, et al. Gerenciamiento en enfermería. 2nd. ed. Rio de Janeiro: Guanabara Koogan; 2012. p. 171-82. 
6. Zunta RSB, Castilho V. Billing of nursing procedures at an intensive care unit. Rev Latino-Am Enfermagem [Internet]. 2011 [cited 2015 Mar 30];19(3):573-80. Available from: http://www.scielo.br/pdf/rlae/v19n3/17.pdf

7. Francisco IMF, Castilho V. A enfermagem e o gerenciamento de custos. Rev Esc Enferm USP [Internet]. 2002 [cited 2018 Dec 08];36(3):240-4. Available from: http://www.scielo.br/pdf/reeusp/v36n3/v36n3a04.pdf

8. Vieira GCG, Bento LA. Gestão de custos hospitalares: o conhecimento do enfermeiro. Rev Uningá [Internet]. 2016 [cited 2018 Aug 12];48(1):56-60. Available from: http://revista.uninga.br/index.php/uninga/article/view/1284/904

9. Everett LQ. Accountable care organizations: the role of APNs. Nurse Leader [Internet]. 2013 [cited 2018 Aug 12];1 1(6):45-6. Available from: https://www.sciencedirect.com/science/article/abs/pii/S1541461213002346

10. Phillips RL Jr, Bazemore AM, Peterson LE. Effectiveness over efficiency: underestimating the primary care physician shortage. Med Care. 2014;52(2):97-8. doi: 10.1097/mlr.0000000000000047

11. Mensik JS. Nursing's role and staffing in accountable care. Nurs Econ [Internet]. 2013[cited 2018 Aug 12];31(5):250-3. Available from: https:// pubmed.ncbi.nlm.nih.gov/24294651

12. Souza MT, Silva MD, Carvalho R. Revisão integrativa: o que é e como fazer. Einstein [Internet]. 2010 [cited 2015 Oct 18];8(1):102-6. Available from: http://www.scielo.br/pdf/eins/v8n1/pt_1679-4508-eins-8-1-0102.pdf

13. The Joanna Briggs Institute. Reviewers' manual: 2014 edition [Internet]. Adelaide: JBl; 2014 [cited 2018 Aug 12]. Available from: http:// joannabriggs.org/assets/docs/sumari/reviewersmanual-2014.pdf

14. Liberati A, Altman DG, Tetzlaff J, Mulrow C, Gøtzsche P, loannidis JPA, et al. The PRISMA statement for reporting systematic reviews and meta-analyses of studies that evaluate health care interventions: explanation and elaboration. PLoS Med[Internet]. 2009[cited 2017 Sep 13];6(7):e1000100. Available from: https://www.bmj.com/content/339/bmj.b2700

15. Lopes CMM, Galvão CM. Surgical positioning: evidence for nursing care. Rev Latino-Am Enfermagem [Internet]. 2010 [cited 2016 Mar 03];18(2):287-94. Available from: http://www.scielo.br/pdf/rlae/v18n2/21.pdf

16. Gouvêa AL, Lima AFC. Custo direto da instalação, manutenção e desligamento da bomba de analgesia controlada pelo paciente. Rev Esc Enferm USP [Internet]. 2014 [cited 2018 Aug 12];48(1):106-11. Available from: http://www.scielo.br/pdf/reeusp/v48n1/pt_0080-6234-reeusp-48-01-104.pdf

17. Nobrega CR, Lima AFC. Procedures' costs related to outpatient chemotherapy treatment of women suffering from breast cancer. Rev EsC Enferm USP. 2014;48(4):699-705. doi: 10.1590/S0080-623420140000400018

18. Ferreira GS, Aguiar MC, Lima AFC. Custo da instalação e desligamento de hemodiálise em pacientes com cateter venoso central. Rev Eletrôn Enferm [Internet]. 2014[cited 2020 Sep 16];16(4). Available from: http://revistas.ufg.br/index.php/fen/article/view/23044

19. Lee M, Moorhead S, Clancy T. Determining the cost-effectiveness of hospital nursing interventions for patients undergoing a total hip replacement. J Nurs Manag [Internet]. 2014 [cited 2018 Aug 12];22(7):825-36. Available from: https://onlinelibrary.wiley.com/doi/abs/10.1111/jonm.12022

20. Jenkins $P$, Welton J. Measuring direct nursing cost per patient in the acute care setting. J Nurs Adm. 2014;44(5):257-62. doi: 10.1097/ nna.0000000000000064

21. Keeler M, Haas BK, Northam S, Nieswiadomy M, McConnel C, Savoie L. Analysis of costs and benefits of transparent, gauze, or no dressing for a tunnelled central venous catheter in Canadian stem cell transplant recipients. Can Oncol Nurs J [Internet]. 2015 [cited 2018 Aug 12];25(3):289-98. Available from: http://www.canadianoncologynursingjournal.com/index.php/conj/article/view/574/572

22. Lima AF, Costa, Ortiz DR. Direct cost of development and documentation of the nursing process. Rev Bras Enferm [Internet]. 2015 [cited 2018 Dec 09];68(4):683-9. Available from: http://www.scielo.br/pdf/reben/v68n4/en_0034-7167-reben-68-04-0683.pdf

23. Hsiao J, Lima AFC. Direct cost of hemodialysis in an adult intensive care unit. Cogitare Enferm [Internet]. 2015 [cited 2018 Dec 08];20(4):67583. Available from: https://revistas.ufpr.br/cogitare/article/view/41782/26627

24. Tomé MF, Lima AFC. Custo direto do reprocessamento de campos cirúrgicos de tecido de algodão: um estudo de caso. Rev Esc Enferm USP [Internet]. 2015 [cited 2018 Aug 12];49(3):494-501. Available from: http://www.scielo.br/pdf/reeusp/v49n3/pt_0080-6234-reeusp-49-03-0494.pdf

25. Lima AFC, Castilho V, Rogenski NMB, Baptista CMC, Rogenski KE. Custos da implantação de um protocolo de prevenção de úlceras por pressão em um hospital universitário. Rev Eletrôn Enferm [Internet]. 2015 [cited 2018 Aug 12];17(4). Available from: https://revistas.ufg.br/ fen/article/view/31051/20672

26. Noddeskou LH, Hemmingsen LE, Hørdam B. Elderly patients' and nurses' assessment of traditional bed bath compared to prepacked single units: randomised controlled trial. Scand J Caring Sci [Internet]. 2015 [cited 2018 Aug 2];29(2):347-52. Available from: https://onlinelibrary. wiley.com/doi/abs/10.1111/scs.12170

27. Lima AFC, Castilho V. Body mobilization for prevention of pressure ulcers: direct labor costs. Rev Bras Enferm [Internet]. 2015 [cited 2018 Aug 12];68(5):930-6. Available from: http://www.scielo.br/pdf/reben/v68n5/en_0034-7167-reben-68-05-0930.pdf

28. Lima AFC, Castilho V, Rogenski NMB, Baptista CMC, Rogenski KE. Direct cost of dressings for pressure ulcers in hospitalized patients. Rev Bras Enferm [Internet]. 2016 [cited 2019 Jan 2];69(2):290-7. Available from: http://www.scielo.br/pdf/reben/v69n2/0034-7167-reben-69-02-0290.pdf

29. Melo TO, Lima AFC. Cost of nursing most frequent procedures performed on severely burned patients. Rev Bras Enferm [Internet]. 2017 [cited 2018 Dec 09];70(3):481-8. Available from: http://www.scielo.br/pdf/reben/v70n3/0034-7167-reben-70-03-0481.pdf

30. Lima AFC. Direct cost of monitoring conventional hemodialysis conducted by nursing professionals. Rev Bras Enferm [Internet]. 2017 [cited 2018 Aug 12];70(2):357-63. Available from: http://www.scielo.br/pdf/reben/v70n2/0034-7167-reben-70-02-0357.pdf 
31. Whitty JA, Mclnnes E, Bucknall T, Webster J, Gillespie BM, Banks M, et al. The cost-effectiveness of a patient centred pressure ulcer prevention care bundle: Findings from the INTACT cluster randomised trial. Int J Nurs Stud [Internet]. 2017 [cited 2018 Aug 12];75:35-42. Available from: https://www.sciencedirect.com/science/article/pii/S0020748917301396?via\%3Dihub

32. Tolentino ACMS, Peregrino, AAF, Marta CB, Silva RCL, Schutz V. O custo do cateterismo vesical de demora nos pacientes internados na Unidade de Terapia Intensiva. Rev Pesqui Cuid Fundam [Internet]. 2017 [cited 2018 Aug 12];9(4):1170-6. Available from: http://www.seer. unirio.br/index.php/cuidadofundamental/article/view/6310/pdf

33. Vaghetti $H$, Reis $D$, Kerber NC, Azambuja E, Fernandes G. Percepções dos enfermeiros acerca das ações administrativas em seu processo de trabalho. Rev Bras Enferm [Internet]. 2004 [cited 2018 Aug 12];57(3):316-20. Available from: http://www.scielo.br/pdf/reben/v57n3/ a12v57n3.pdf

34. Yin RK. Case Study Research: Design and Methods. 5th ed. London: SAGE; 2014.

35. Martins E. Contabilidade de custos. 10th Edition. São Paulo: Atlas, 2010.

36. Secoli SR, Nita ME, Ono-Nita SK, Nobre M. Avaliação de tecnologia em saúde. Il. A análise de custo efetividade. Arq Gastroenterol 2010;47(4):329-333. doi: 10.1590/S0004-28032010000400002

37. Oliveira WT, Rodrigues AVD, Haddad MCL, Vannuch MTO, Taldivo MA. Concepções de enfermeiros de um hospital universitário público sobre o relatório gerencial de custos. Rev Esc Enferm USP. 2012;46(5):1 184-91. doi: 10.1590/S0080-62342012000500021

38. Gonçalves MA, Zac Jl, Amorim CA. Gestão estratégica hospitalar: aplicação de custos na saúde. Rev Adm FACES J [Internet]. 2009 [cited 2018 Jun 19];8(4):161-79. Available from: http://www.redalyc.org/pdf/1940/194014451009.pdf 